\title{
Buschke-Loewenstein tumour of the penis
}

\section{A case report}

\author{
JANINA M HARVEY,* E GLEN,† AND G S WATSON‡ \\ From the *Department of Genitourinary Medicine, Falkirk and District Royal Infirmary, Falkirk; \\ †Walton Urological Teaching and Research Centre, Southern General Hospital, Glasgow; and \\ $\ddagger$ Ballochmyle Hospital, Ayrshire
}

SUMMARY A 30 year old man presented with a large, penile, warty growth. The histopathological features were consistent with giant condylomata acuminata. After successful treatment with 5-fluorouracil cream and electrocautery some growth recurred at the excision site. Subtotal amputation of the penis was performed to remove the warty base. Because of the infective component of giant condylomata acuminata patients as well as their wives should be examined regularly.

\section{Introduction}

Buschke and Loewenstein ${ }^{1-3}$ and $\mathrm{Frei}^{4}$ were the first to describe several cases of giant condylomata acuminata in detail. Giant condylomata acuminata are clinically malignant but histologically benign and usually occur on the penis, vulva, and in the anorectal areas. This warty lesion is distinguishable from simple condylomata acuminata by the fact that it penetrates and compresses the deeper tissues. We report a case of Buschke-Loewenstein tumour of the penis, which indicates the difficulties associated with selected methods of treatment.

\section{Case report}

A 30 year old married man presented at the genitourinary clinic in Ayrshire on 21 May 1980 with a penile warty growth of six years' duration. He had been having pressure discomfort locally and had noticed blood in the urine for several months. He denied extramarital sexual contact and had not had treatment for any genitourinary condition previously.

On examination he had a large, foul-smelling, ulcerated, warty growth resembling an extensive malignant growth and affecting the distal end of the penis with gross distortion of the urethral meatus, prepuce, and shaft of the penis (fig 1). The swelling

Address for reprints: Dr J M Harvey, Department of Genitourinary Medicine, Falkirk and District Royal Infirmary, Major's Loan, Falkirk FK1 SQE

Accepted for publication 8 January 1983

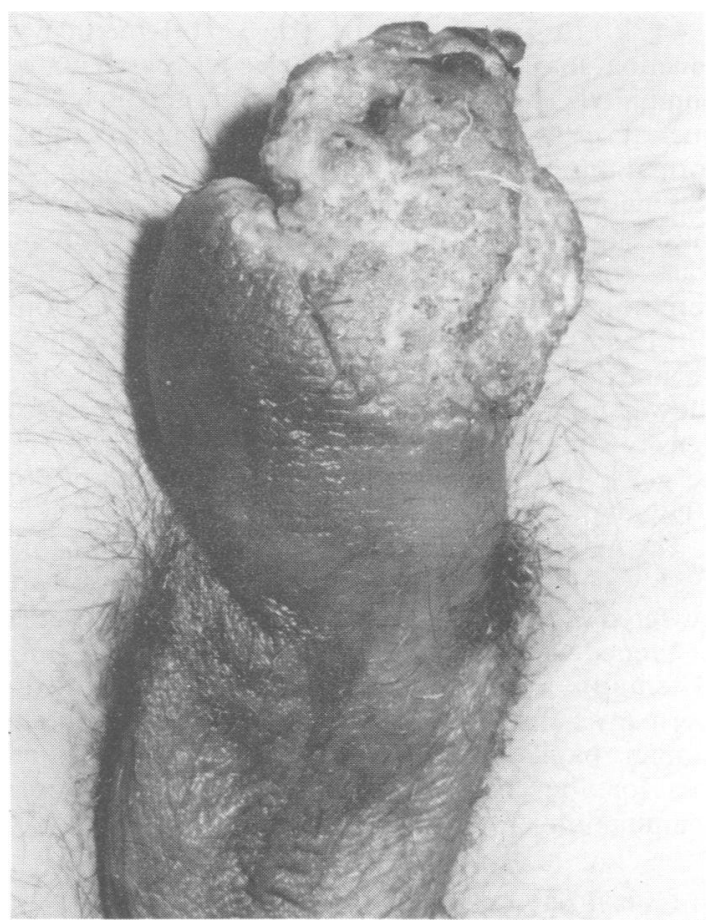

FIG 1 Ulcerated warty growth of distal third of penis.

was firm and penetrated the corpus spongiosum. There was no inguinal lymphadenopathy. Haematuria and mild albuminuria were confirmed by routine urine tests. Serological test results for syphilis were negative. The patient's wife was also examined and no evidence of warts was seen. 
INVESTIGATIONS

Multiple biopsy specimens were examined in May 1980. Histologically, there was a benign papillomatous proliferation of the squamous epithelium. The epithelial cells showed cytoplasmic vacuolation. Some cells showed necrosis and there was a mild nonspecific inflammatory infiltrate in the underlying stroma. There was no epithelial cell dysplasia and no invasive carcinoma. The features were consistent with condylomata acuminata, and the lesion was possibly of viral origin.

Full blood count was normal, although the erythrocyte sedimentation rate was $24 \mathrm{~mm} /$ first hour. Liver function tests were normal. Serum calcium was $2.4 \mathrm{mmol} / \mathrm{l}$ and serum phosphate $1.5 \mathrm{mmol} / \mathrm{l}$. Serological tests for recent infection with psittacosis, lymphogranuloma venereum, Coxiella burneti, Mycoplasma pneumoniae, influenza virus $\mathrm{A}$ and $\mathrm{B}$, adenovirus, parainfluenza virus types 1,2 , and 3 , herpes simplex virus, measles virus, cytomegalovirus, varicella zoster, and Coxsackie virus B1 to B5 were negative. Serum immunoglobulins were normal: IgM $1.4 \mathrm{~g} / \mathrm{l}, \mathrm{IgA} 5.0 \mathrm{~g} / \mathrm{l}$, and IgG $10.0 \mathrm{~g} / \mathrm{l}$. Lymphocyte function studies showed no depressed cell mediated immunity. The numbers of blood $\mathrm{T}$ and $\mathrm{B}$ mononuclear cells were normal and lymphocyte transformation studies showed normal response to stimulation by phytohaemagglutinin and pokeweed mitogen. Serum antibody directed against human wart virus was detected using papillomavirus common core antigen against tissue sections (Professor Rona MacKie, university department of dermatology, Glasgow). Electron microscopy showed no viral particles, but there was an increased density of chromatin in some cells (Dr U Desselberger, Institute of Virology, University of Glasgow).

The major part of the material excised in January 1981 was lyophilised after suspension in phosphate buffered saline, and hybridisation studies with probes of cloned viral DNA were performed by Dr Lutz Gissmann, Institute of Virology, Freiburg, Germanys: the warty tumour was found to contain human papillomavirus (HPV) 6DNA and could therefore be characterised as a typical condyloma acuminatum.

\section{TREATMENT AND RESULTS}

Giant condyloma acuminatum or Buschke-Loewenstein tumour was diagnosed on the basis of the absence of neoplastic change. 5-Fluorouracil cream was applied with an excellent initial response. After a month the wart had apparently almost resolved. Two weeks later there was recurrence with local secondary infection, and co-trimoxazole was given for one week.

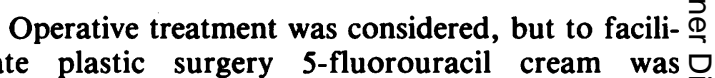
reapplied. Co-trimoxazole was again given as a short $\stackrel{\oplus}{.}$ course and the 5-fluorouracil cream applied for six $\vec{F}$ weeks.

The patient was admitted to hospital in January 1981 for conservative surgical management to excise the tumour, preserving as much of the penis as possible. Electrocautery was used. In some areas the $\varrho$ lesion had the appearance of carcinoma to the naked $\%$ eye, but histopathological findings (fig 2) were $\vec{\circ}$ similar to those found in June 1980. Subsequently, some warty growth recurred on the excision site and $\vec{\omega}$ Retinoid (Tigasson Caromatic), the oral vitamin A supplement, was suggested for use as in hand papillomata. The condition did not improve with this treat- of ment, and subtotal amputation of the penis was performed with complete removal of the warty base; $\omega$ the inguinal nodes were not removed. The patient made a good recovery and so far has remained well; both he and his wife have adjusted well psychologically.

\section{Discussion}

Human warts are caused by one of several papillomaviruses depending on the skin site. Although several distinct types and subtypes of human papillomaviruses (HPV) have been identified recently by serological and nucleic acid hybridisation tests, a $\stackrel{2}{\circ}$ successful method for actual propagation of the virus in vitro has not been developed so far. The nature of $\overrightarrow{\vec{B}}$ viral replication during the process of keratinisation 3 of epidermal cells in vivo indicates that a highly specialised cellular environment is required. In the common wart (verruca vulgaris) HPV-1 has been identified as the most prevalent type. Two additional types are designated HPV-2 and HPV-4. ${ }^{6-8}$ One distinct type (HPV-3) is associated with the flat wart (verruca plana). ${ }^{9}$ In epidermodysplasia verruciformis, HPV-3 and HPV-5 have been identified. ${ }^{10}$ Human papilloma virus (HPV-6) has been found in biopsy material from this and other patients with $\frac{7}{0}$ Buschke-Loewenstein tumours; ${ }^{5}$ this new finding in Buschke-Loewenstein tumours confirms the viral o origin of both this condition and condylomata $N$ acuminata. Whether or not there are distinct $N$ subtypes of HPV-6 or as yet unidentified papillo- $\omega$ mavirus types in atypical condylomata acuminata-that is, in Buschke-Loewenstein tumoursremains to be seen. The possibility of an association $\Phi$ between this specific viral type and human genital cancer must be treated with caution.

Eng has drawn attention to the subtle histological $\stackrel{\circ}{\circ}$ differences between condyloma acuminatum and $\stackrel{?}{?}$ giant condyloma acuminatum. ${ }^{11}$ Although 


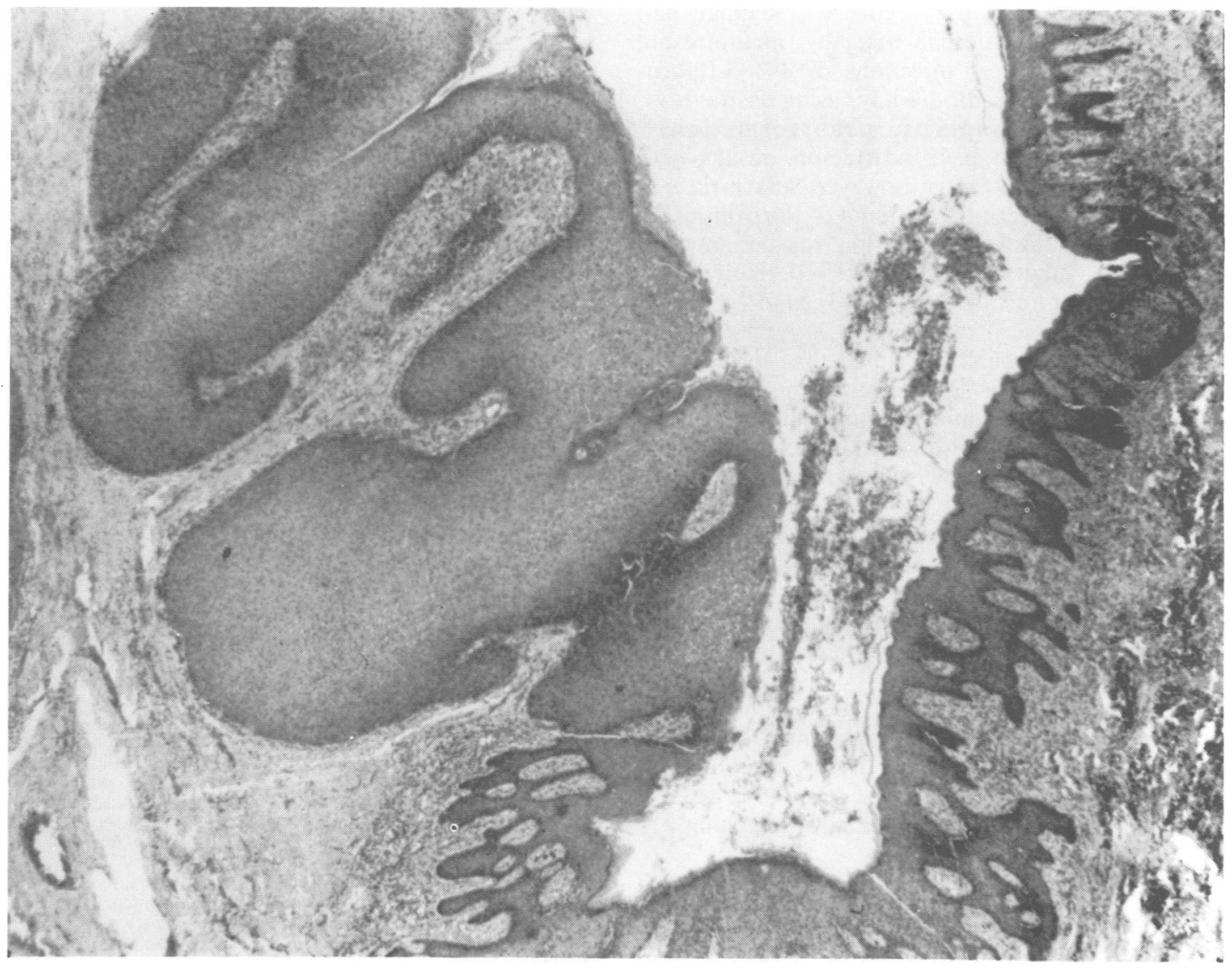

FIG 2 Biopsy specimen of warty lesion showing transition from normal to exaggerated papillomatous proliferation of squamous epithelium and mild non-specific inflammatory infiltrate in stroma (no invasion of stroma identified).

(Haematoxylin and eosin, $\times$ 100).

histologically benign, the clinical presentation of this particular case was of an invasive, fungating, malodorous, "heaped up," warty lesion. The condition developed untreated over a period of six years. After his first attendance the patient attended the clinic regularly; he had a stable personality but other patients have been known to default. The importance of attending the same doctor cannot be overemphasised.

The association between hypercalcaemia and this condition, which has been reported in one case, ${ }^{12}$ was not evident in our patient. The reported case showed that the tumour was acting as paraendocrine tissue and was releasing a parathyroid-like hormone. ${ }^{12}$

The clinical features of giant condylomata acuminata indicate the need for a more aggressive approach to treatment despite their benign histology. Nevertheless, Loewenstein recommended minor surgery at the onset before amputation was considered. ${ }^{3}$ Conservative management was also recommended by Treite. ${ }^{13}$ This option should not be discounted in view of the fact that giant condyloma acuminatum may remain benign for 25 years. ${ }^{14}$

Alternative forms of treatment were considered in our patient; electrocautery, which was used by Robinson, ${ }^{15}$ was not sufficient as our patient delayed seeking advice. Podophyllin was not used because it is usually too toxic in this particular condition; it can cause sloughing and also histological changes which are indistinguishable from carcinomas. ${ }^{16}$ Bedi et al, however, reported a case with urinary fistula which responded to podophyllin $25 \%$. ${ }^{17}$ Laser treatment would have required an experienced operator; although it has been used in simple condylomata acuminata it would not have been easy to assess the depth of the tumour. ${ }^{18}$ 
Antiviral treatment has been used; Redman had little success using thiotepa topically, methotrexate orally, and later local injections of $1 \%$ 5-fluorouracil. ${ }^{19}$ In the past radiotherapy, using deep $x$-rays, has produced anaplastic transformation. ${ }^{20}$ Loewenstein did not have satisfactory results with radium or $x$-rays. ${ }^{3}$ Recently, however, Salaverria et al found that treatment of carcinoma of the penis using the iridium mould technique, thus sparing amputation, had a high success rate. ${ }^{21}$ Perhaps giant condyloma acuminatum could also respond favourably.

Our patient eventually accepted that surgery was the best course. At his age, however, the question of further children and family planning also had to be considered. Although this condition has usually been found in patients over 40 years and the older age group, Muhlpfordt ${ }^{22}$ and Bedi et al ${ }^{17}$ each reported two cases in 19 year old patients. Nevertheless, amputation was carried out in our patient. The inguinal lymph glands were conserved; in other reports of Buschke-Loewenstein tumour where the glands were resected no evidence of malignancy was found on histology.

The infective component of giant condylomata acuminata indicates that not only should the patient himself have yearly urological follow up examinations but his wife should also be assessed regularly, preferably routinely during cytological screening.

We thank Dr Lutz Gissman and Professor H Zur Hausen, Institute of Virology, Freiburg, for performing the DNA hybridisation studies, $\mathrm{Dr} \mathrm{U}$ Desselberger for help with the virological diagnostic tests, Professor Rona MacKie for carrying out the immunological screen, and $\mathrm{Dr}$ A McMillan, department of genitourinary medicine, University of Edinburgh, Professor Calman, and the medical staff of the university department of oncology, Glasgow for their helpful advice. We also thank Mr McKie, medical illustration, university department of dermatology, the departments of pathology and medical illustration, Southern General Hospital, and Mrs Betty McEwan for her patient secretarial help.

\section{References}

1. Buschke A. In: Neisser A, ed: Stereoskopischer Medicinischer $\frac{\square}{\oplus}$ Atlas, Cassel, Fischer, (1896). Cited by Loewenstein 1939.

2. Buschke A, Loewenstein LW. Bezeihungen der spitzen $\Rightarrow$. kondylome zu den carcinomen des penis. Archiv fur Dermatologie und Syphilis 1931;163:30-46.

3. Loewenstein LW. Carcinoma-like condylomata acuminata of the penis. Med Clin North Am 1939;23:789-95.

4. Frei W. Giant condylomata acuminata. Archiv fur $\overline{\bar{s}}$ Dermatologie und Syphilis 1930;160: 109-14.

5. Gissmann L, De Villiers EM, Zur Hausen H. Analysis of $\underset{\mathcal{Q}}{\mathbb{Q}}$ human genital warts (condylomata acuminata) and other 0 genital tumours for human papillomavirus type 6 DNA. Int $J \mathscr{c}$ Cancer 1982; 29: 143-6.

6. Gissmann L, Zur Hausen H. Human papillomavirus DNA. Physical mapping and genetic heterogenicity. Proc Natl Acad Sci 1976; 73: 1310-3.

7. Gissmann L, Pfister $H$, Zur Hausen $H$. Human papilloma $\sigma_{\overparen{\sigma}}$ viruses (HPV): characterisation of four different isolates. 0 Virology 1977; 76:569-80.

8. Orth G, Favre M, Croissant $O$. Characterisation of a new type of human papillomavirus that causes skin warts. J Virol 1977; 24: 108-20.

9. Orth G, Favre M, Jablonska S, Brylak K, Croissant O. Viral $N$ sequences related to a human skin papillomavirus in genital $\omega$ warts. Nature 1978;275:334-6.

10. Orth G, Jablonska S, Favre M, Croissant O, JarzabekChorzelska M, Rzega G. Characterisation of two new types of human papillomaviruses in lesions of epidermodysplasia $\square$ verruciformis. Proc Natl Acad Sci 1978; 75: 1537-41.

11. Eng AM, Morgan JE, Blekys I. Giant condyloma acuminatum. Cutis 1979;24:203-7.

12. Bennett $R$, Decherd J, Heaton CL. Hypercalcaemia associated with giant condylomata acuminata. Acta Derm Venereol (Stockh) 1974;54:407-11.

13. Treite $P$. Über die karzinomentstehungen auf spitzen kondylomen. Zentralbl Gynaekol 1941;65:1096-100.

14. Towpik $K$. Chróścicki S. A case of giant condylomata acuminata lasting 25 years. Przegl Dermatol 1979; 66:55-7.

15. Robinson JK. Extirpation by electrocautery of massive lesions of condyloma acuminatum in the genito-perineo-anal region. $J$ Dermatol Surg Oncol 1980; 6: 733-8.

16. Dreyfuss $W$, Neville WE. Buschke-Loewenstein tumours (giant $\stackrel{D}{\mathbb{Q}}$ condylomata acuminata). Am J Surg 1955;90: 146-50.

17. Bedi TR, Pandhi RK. Buschke-Loewenstein's tumour presenting with urinary fistula. $B r J$ Vener $D i s$ 1972; 53:200-2.

18. Baggish MS. Carbon dioxide laser treatment for condylomata acuminata venereal infections. Obstet Gynecol 1980;55:711-5.

19. Redman JF, Turley JT. Failure of chemotherapy in treatment of giant condylomata acuminata. South Med J 1974;67:742-4.

20. Kraus FT, Perez-Mesa C. Verrucous carcinoma. Clinical and $\stackrel{\infty}{\square}$ pathological study of 105 cases involving oral cavity, larynx and genitalia. Cancer 1966; 19:26-38.

21. Salaverria JC, Hope-Stone HF, Paris AMI, Molland EA, Blandy JP. Conservative treatment of carcinoma of the penis. ? Br J Urol 1979;51:32-7.

22. Muhlpfordt $H$. One case in a 19 year old boy of giant condylomata acuminata. Dermatol Wochenschro 1928;87:1403-12. 